\title{
Seasonal and diel abundance of viruses and occurrence of lysogeny/bacteriocinogeny in the marine environment
}

\author{
Sunny C. Jiang, John H. Paul* \\ Department of Marine Science, University of South Florida, 140 Seventh Ave. S., St. Petersburg, Florida 33701, USA
}

\begin{abstract}
To understand the role of viruses in the marine environment, it is important to know the factors affecting their temporal distribution and the abundance of lysogens. We therefore performed a seasonal and a diel study on viral distribution in Tampa Bay, Florida, USA, and detected the abundance of lysogens and bacteriocinogens amongst marine bacterial isolates from diverse marine environments. We investigated the distribution of viruses, bacterial direct counts, chlorophyll a (chl a), salinity and temperature during a 13 mo period in the Tampa Bay estuary. The results indicated that the viral population had a strong seasonal pattern with the highest concentrations $\left(2.0 \pm 0.8 \times 10^{7}\right)$ in the summer and lowest $\left(4.8 \pm 1.4 \times 10^{6}\right)$ in the winter Viral abundance was negatively correlated with salinity $(r=-0.803)$, and positively correlated with chl a concentration $(r=0.725)$. A diel study in a seawater mesocosm indicated that viral abundance did not vary on a diel rhythm, but rather peaked after a maximum in bacterial abundance and chl a. Dissolved DNA concentrations displayed diel rhythmicity, suggesting that viruses were not the main source of dissolved DNA. An estimation of the percentage of the bacterial standing stock lysed by viruses based on $4 \mathrm{~h}$ intervals ranged from 3.0 to $53.3 \%$ per day. Screening bacterial isolates for the presence of inducible prophages indicated that $43 \%$ were lysogens or bacteriocinogens, suggesting that lysogeny and bacteriocinogeny are common in the marine environment.
\end{abstract}

KEY WORDS: Viruses - Lysogeny · Marine environment

\section{INTRODUCTION}

The existence of viruses in the marine environment has been known for nearly half a century (e.g. Kriss \& Rukina 1947, Spencer 1955). However, the relative abundance of viruses in the marine environment was not recognized until 1988 (Sieburth et al. 1988, Bergh et al. 1989). Because viruses are obligate parasites, it has been hypothesized that they control the population density of their hosts in natural ecosystems. Early studies of bacteriophages and their hosts in estuarine environments indicated that an increase in the concentration of sensitive bacteria was a precondition for the growth of the bacteriophage population (Ahrens 1971). Very recently, microbial ecologists have estimated that viruses may cause 30 to $72 \%$ of the bacterial population mortality (Proctor \& Fuhrman 1990, 1991, 1992,

- Corresponding author
Heldal \& Bratbak 1991, Bratbak et al. 1992). Natural viral populations may also play a role in the mortality of marine phytoplankton (Suttle et al. 1990, Suttle 1992, Suttle \& Chan 1993), and the addition of concentrated native viral populations to seawater reduced primary production by as much as $78 \%$ (Suttle et al. 1990, Suttle 1992). Although the first attempt to incorporate viruses into a carbon budget resulted in a 6 -fold overestimation of viral lysis of the bacterial population (Bratbak et al. 1992), the results support the idea that viral lysis may be a quantitatively significant process that needs to be incorporated into budgets of microbial carbon transfer.

Systematic studies of the spatial distribution of viruses in the ocean have suggested, in most cases, that viral abundance decreases from estuarine to offshore environments and from surface to depth, with an occasional subsurface maximum (Boehme et al. 1993, Cochlan et al. 1993). Viral abundance was found to correlate with bac- 
terial abundance (Paul et al. 1991, Cochlan et al. 1993), chl a concentration (Paul et al. 1993), or both (Boehme et al. 1993). These results suggest that bacterioplankton and phytoplankton were the major viral hosts.

Viruses were also found to be dynamic members of the microbial community, with population density changes on time scales of a month (Bratbak et al, 1990), a week (Børsheim et al. 1990) and even hours (Heldal \& Bratbak 1991). Significantly higher viral counts were found in August and October samplings than in those taken in April, June and September (Wommack et al. 1992), although no systematic sampling for the seasonal distribution of viral population has yet been performed.

Viruses can exist in the environment as free virions or as a prophage inside a lysogenic host (Moebus 1987). To obtain an understanding of the mechanisms governing the distribution of bacteriophages in natural waters, it is important to consider the difference between lytic and temperate phages (Heldal \& Bratbak 1991, Bratbak et al. 1992). Because more than $90 \%$ of known phages are temperate (Freifelder 1987), it is reasonable to believe that most phages in aquatic environments are temperate rather than virulent (Heldal \& Bratbak 1991). Thus, the production of new viral particles in natural waters may depend on the induction of prophages in lysogenic bacteria (Bratbak et al. 1992). The occurrence of lysogeny in a freshwater environment was evaluated recently: between 1 and $7 \%$ of the Pseudomonas aeruginosa isolates tested gave positive results using the criterion of release of plaque-forming units infectious on laboratory strains of $P$. aeruginosa (Replicon \& Miller 1990). Colony hybridization using various DNA probes specific for $P$. aeruginosa phages revealed that up to $70 \%$ of freshwater Pseudomonas sp. isolates contained phagespecific DNA (Ogunseitan et al. 1990, 1992). However, little information exists to date concerning the abundance and distributions of lysogenic bacteria and temperate phages in the marine environment.

Here we present the seasonal and diel abundance of viruses in the estuarine environment of Tampa Bay, Florida, USA, and relate this abundance to the other biological parameters. We also present the first report on the occurrence of lysogeny and bacteriocinogeny from a diversity of marine environments.

\section{MATERIAL AND METHODS}

Sampling sites. Water samples for a seasonal viral abundance study were taken from Tampa Bay, Florida, USA, at the St. Petersburg city pier every 2 wk for 13 mo from December 1990 to December 1991. In addition to viral direct counts (see below), bacterial direct counts, chl a concentration, temperature and salinity were also determined for each sample.
Seawater (180 I) was also collected for a diel study from the St. Petersburg city pier on August 3, 1992 by surface pumping. The water was incubated in a 2001 polyethylene tank in front of the University of South Florida Marine Science Building. The top of the tank was covered by neutral-density screening to reduce light intensity by $66 \%$. A refrigerated recirculator (Coolflow, Neslab Instrument, Inc., Portsmouth, NH, USA) was used to recirculate antifreeze coolant within a $15 \mathrm{~m}$ long, $0.8 \mathrm{~cm}$ diameter tygon tube inside the tank to regulate the water temperature between 25 and $30^{\circ} \mathrm{C}$. Samples were taken every $4 \mathrm{~h}$ for $36 \mathrm{~h}$ for viruses, bacteria, chl $a_{1}$ dissolved DNA, temperature and salinity measurements.

For the detection of lysogenic bacteria in the marine environment, water samples were collected from the estuarine environment of the St. Petersburg Pier and Northshore Beach, Tampa Bay, in May 1991. Surface water samples were also taken in January 1992 from Key Largo, including samples from a man-made seawater canal adjacent to houses, hotels and a marina and boat yard, the seagrass environment of Hawk Channel, the coral-reef environment of Mosquito Bank and French Reef, the edge of the Florida shelf break, the mangrove environment of Blackwater Sound, and Tarpon Sound, an enclosed embayment on the west side of Key Largo (Paul et al. 1993). Water samples were collected using acid-washed carboys at Key Largo offshore stations, and with a dip bucket for inshore sampling.

Direct enumeration of viruses. Seawater samples (5 1) were concentrated by a Membrex Benchmark vortex flow filtration unit (Garfield, NJ, USA) with a $100 \mathrm{kD}$ filter to 30 to $50 \mathrm{ml}$ as described elsewhere (Paul et al. 1991, Jiang et al. 1992). The concentrated retentates were fixed with $2 \%$ electron-microscopegrade glutaraldehyde immediately after concentration. The fixed samples were further concentrated by ultracentrifugation at $201000 \times \mathrm{g}$ for $90 \mathrm{~min}$. The pellet fractions were collected for direct enumeration of viruslike particles by transmission electron microscopy (TEM; Paul et al. 1991). The final viral counts and standard deviations were calculated from the means of 4 electron microscope grid fields (a minimum of 30 counts in each field).

Measurement of dissolved DNA. For the measurement of dissolved DNA, water samples were filtered through Whatman GF/D and $47 \mathrm{~mm}$ diameter, $0.2 \mu \mathrm{m}$ Nuclepore filters at a vacuum of $<150 \mathrm{~mm} \mathrm{Hg}$ (Paul et al. 1987). Five replicate filtrates $(125 \mathrm{ml}$ each) were ethanol-precipitated at $-20^{\circ} \mathrm{C}$ overnight. Two of these replicate samples were spiked with calf thymus DNA to determine efficiency of recovery (DeFlaun et al. 1986). The precipitates were harvested by centrifugation, and then solubilized as previously described 
(DeFlaun et al. 1986). DNA content was determined in concentrated extracts by the Hoechst 33258 method (Paul \& Myers 1982) and subsamples were DNase treated to detect nonspecific fluorescence.

Bacterial direct counts and chlorophyll a determination. Samples for bacterial direct counts were stained with 2,4-diamidino-2-phenylindole (DAPI; Aldrich Chemical Co.), and $1 \mathrm{ml}$ of each sample was filtered on a black $25 \mathrm{~mm}, 0.2 \mu \mathrm{m}$ Nuclepore filter and counted by epifluorescence microscopy as previously described (Paul 1982). Samples for chl a analysis were collected on Whatman GF/F filters. Chlorophyll a was determined fluorometrically by the method of HolmHansen \& Riemann (1978).

Selection of lysogenic and bacteriocinogenic bacteria from marine isolates. Marine bacteria were isolated from different environments on artificial seawater medium agar plates (ASWJP; Paul 1982). Fiftyone isolates were tested for the presence of inducible prophage by mitomycin $C$ (Sigma Chemical Co.; Ackermann \& DuBow 1987). Freshly prepared mitomycin $C$ (1 $\mathrm{mg} \mathrm{ml}^{-1}$ in deionized water) was added to mid- $\log$ phase bacterial cultures $\left(O D_{550} \approx 0.6\right)$ to a final concentration of $0.5 \mu \mathrm{g} \mathrm{ml}^{-1}$ The cultures were further incubated and cell density monitored spectrophotometrically every $2 \mathrm{~h}$ for the first $6 \mathrm{~h}$, and then finally overnight (14 to $17 \mathrm{~h}$ ). The cultures in which the optical density decreased or remained the same as when mitomycin $C$ was added were centrifuged at $8000 \mathrm{rpm}$ (5854 $\times g$, SS-34 rotor, Sorvall, Inc.) for $5 \mathrm{~min}$ and supernatants collected for detection of virus-like particles by TEM. The empty phage heads and tail assemblies found in the samples were considered as bacteriocin particles.

Data analysis. Multiple correlation and regression analysis was performed with the Regress It software (Human Systems Dynamics, Inc., Northridge, CA, USA).

\section{RESULTS}

\section{Seasonal viral abundance in Tampa Bay}

Fig. 1a shows the seasonal variation in salinity and temperature in Tampa Bay. Water temperatures were usually $<20^{\circ} \mathrm{C}$ for the winter or dry season, and increased at the end of March and beginning of April. Water temperatures were greatest (ca $30^{\circ} \mathrm{C}$ ) from July to October 1. This period also coincided with the occurrence of the summer rains, as indicated by the decrease in salinity from July through October and November.

A pronounced seasonal pattern in viral abundance was observed (Fig. 1b) with the highest concentration in the summer (wet season) and lowest in the winter

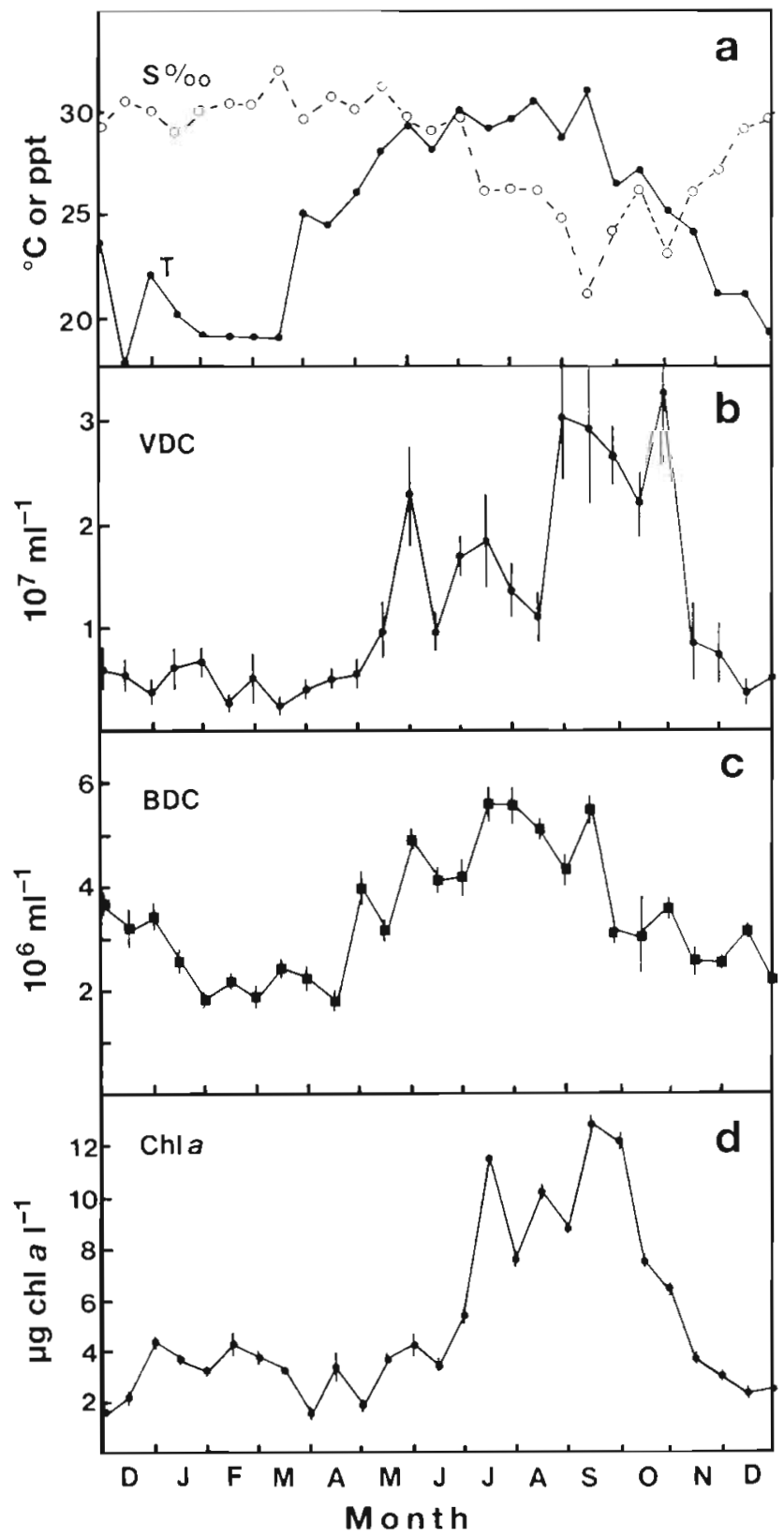

Fig. 1. Seasonal variation in (a) salinity and temperature, (b) viruses, (c) bacteria and (d) chlorophyll a concentrations in Tampa Bay, Florida, USA. Samples were taken semimonthly for 13 mo. S: salinity; T: temperature; VDC: viral direct counts; BDC; bacterial direct counts; Chl a: chlorophyll a. Error bars ( $b$ to d) indicate standard deviations estimated from multiple measurements (for VDC, $\mathrm{n}=4$; $\mathrm{BDC}, \mathrm{n}=2$; Chl $\mathrm{a}, \mathrm{n}=3$ )

(dry season). Viral abundance increased by 1 order of magnitude (from 0.2 to $2.3 \times 10^{7} \mathrm{ml}^{-1}$ ) beginning in May. A second peak in viral abundance was observed in early September with the viral concentration of $3.0 \times 10^{7} \mathrm{ml}^{-1}$. There was a rapid decrease in viral abundance between November 1 and $15\left(3.2 \times 10^{7} \mathrm{ml}^{-1}\right.$ to $8.2 \times 10^{6} \mathrm{ml}^{-1}$ ). 
A seasonal pattern in bacterial abundance was also observed (Fig. 1c). Bacterial direct counts ranged from $1.8 \pm 0.4 \times 10^{6} \mathrm{ml}^{-1}$ in winter months to $5.6 \pm 0.4 \times$ $10^{6} \mathrm{ml}^{-1}$ in summer months. The increase in bacterial direct counts (from mid-April to May) preceded the increase in viral direct counts from $5.13 \times 10^{6} \mathrm{ml}^{-1}$ to $2.31 \times 10^{7} \mathrm{ml}^{-1}$. The increase in bacterial abundance was preceded by an increase in water temperature from 19 to $25^{\circ} \mathrm{C}$ at the end of March. The secondary increase in viral abundance in early September may have resulted from either a bacterial bloom in September or a phytoplankton bloom (as indicated by increased chl a). The second viral peak $\left(3.0 \times 10^{7} \mathrm{ml}^{-1}\right)$ also coincided with lowest salinity resulting from later summer rains.

Chlorophyll a values were also lowest in winter months $\left(1.43 \pm 0.3 \mu \mathrm{M} \mathrm{l}^{-1}\right)$ and highest in summer months $\left(12.8 \pm 0.25 \mu \mathrm{g} \mathrm{l}^{-1}\right)$ (Fig. 1d). The summer chl a increase occurred later than the bacterial and viral increases, starting in mid-June and reaching a peak in July. A secondary peak in chl a occurred in September $\left(12.8 \pm 0.25 \mu \mathrm{g} \mathrm{l}^{-1}\right)$.

Multiple regression analysis for the seasonal study (Table 1) showed that viral direct counts were negatively correlated with salinity $(\mathrm{r}=-0.803)$ and positively correlated with chl a concentration ( $\mathrm{r}=0.725)$, temperature $(\mathrm{r}=0.649)$ and bacterial direct counts $(\mathrm{r}=0.561)$. Bacterial abundance correlated best with temperature $(r=0.793)$. Salinity was also negatively correlated with chl a concentration $(\mathrm{r}=-0.750)$. The results of the stepwise solution of multiple regression analysis with viral direct counts (VDC) as the dependent variable indicated the following relationship:

$$
\mathrm{VDC}=-2.23 \text { (salinity) }+0.676 \text { (temperature })+58.09
$$

where VDC is in $10^{6}$ virus $\mathrm{ml}^{-1}$; salinity is in parts per thousand; and temperature is in ${ }^{\circ} \mathrm{C}(\mathrm{n}=25, \mathrm{r}=0.851$, $F=31.4$ ). These results imply that the variation in viral direct counts could be explained by the variation in salinity and temperature. Using bacterial direct counts or chl a as the dependent variable for the stepwise multiple regression indicated that temperature was the only dependent factor necessary to explain variation in

Table 1. Partial correlation coefficients for the seasonal study in Tampa Bay, Florida, USA. VDC: viral direct counts; BDC: bacterial direct counts; $\mathrm{Chl}$ a: chlorophyll a concentration; Temp.: temperature

\begin{tabular}{|lrrrrr|}
\hline & VDC & BDC & Chl a & Temp. Salinity \\
\hline VDC & 1.000 & & & & \\
BDC & 0.561 & 1.000 & & & \\
Chl a & 0.725 & 0.513 & 1.000 & & \\
Temp. & 0.649 & 0.793 & 0.588 & 1.000 & \\
Salinity & -0.803 & -0.518 & -0.750 & -0.534 & 1.000 \\
\hline
\end{tabular}

the bacterial population $\left(F_{(1,25)}=44.7, \mathrm{r}=0.801\right)$, and that phytoplankton (as indicated by chl a concentration) was only dependent on salinity $\left(F_{(1.25)}=39.4, \mathrm{r}=0.782\right)$.

The virus to bacterium ratio (VBR; Hara et al. 1991, Wommack et al. 1992) for the seasonal study ranged from 0.90 to 9.13. The ratios were higher in early September through the end of October (Fig. 2). The highest VBR (9.13) occurred at the end of October which corresponded with the times of highest viral counts.

\section{Diel viral abundance in an estuarine mesocosm}

The results of a diel viral abundance study are shown in Fig. 3. No diel rhythm of viral abundance was observed. A significant increase $(p<0.01)$ in viral abundance $\left(3.7 \times 10^{7} \mathrm{ml}^{-1}\right)$ occurred at midnight, $32 \mathrm{~h}$ into the diel study. This increase in viral population was preceded by an increase in bacterial abundance $(p<0.01)$ and chl a $(p<0.025)$ concentrations. The increases in bacterial and chl a concentrations may have been caused by the elevation of water temperature in the afternoon. Dissolved DNA values did follow a diel rhythm, with maximum values found at about 20:00 h. The fact that viral direct counts did not follow this peak suggests that dissolved DNA was not the result of DNA in viral populations. Multiple correlation analysis of the data indicated that there was no significant correlation $(\mathrm{n}=10, \mathrm{r}=0.4723, F=0.230, \mathrm{p}>0.5$ ) between any of the parameters in this study.

Because both viruses and bacteria are dynamic members of the marine microbial community, we chose to compute the viral contribution to bacterial mortality on a time scale of hours. A large range in viral decay

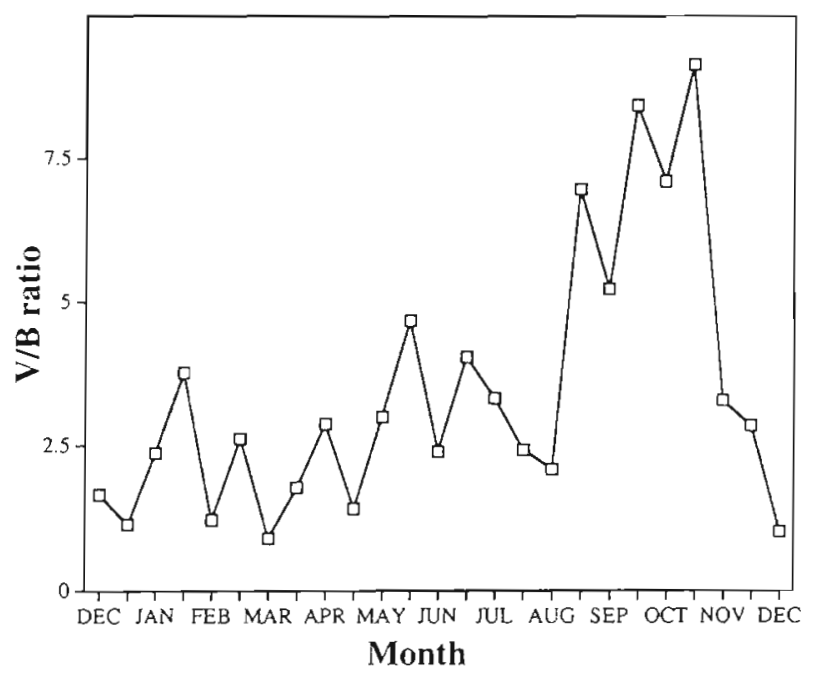

Fig. 2. Seasonal variation in the virus to bacterium (V/B) ratio. Ratios were calculated using the mean value for viral counts and bacterial counts of each sample time 


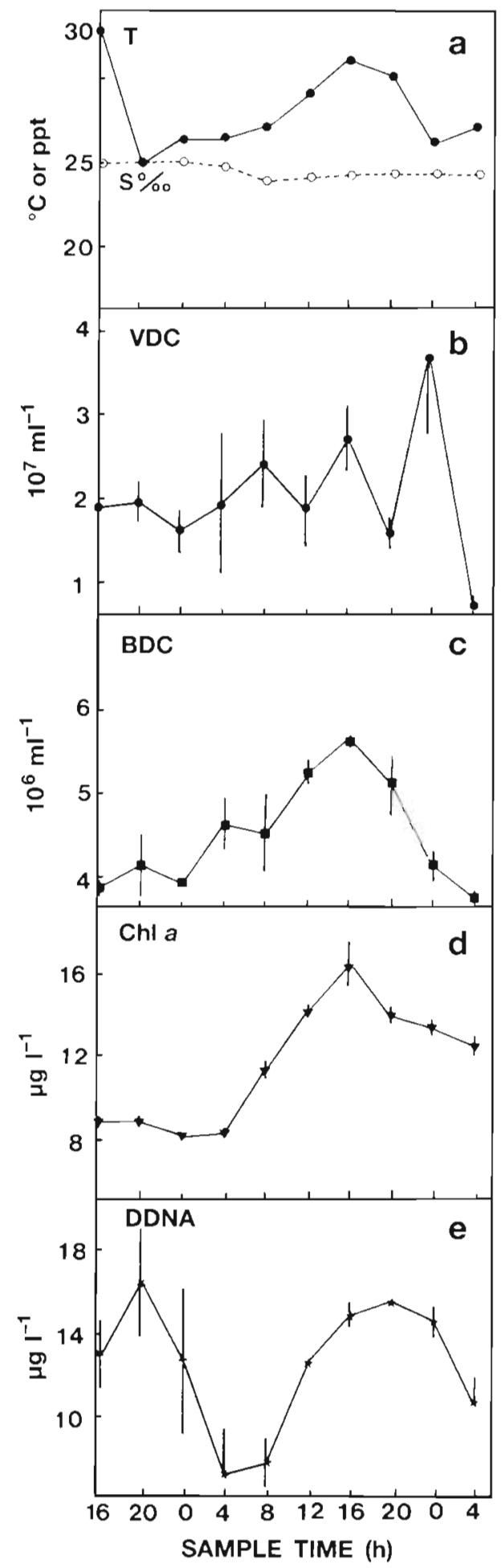

Fig. 3. Diel variation in (a) salinity and temperature, (b) viruses, (c) bacteria, (d) chlorophyll $a$ and (e) dissolved DNA concentrations in estuarine water from St. Petersburg Pier, Florida, USA, enclosed in a 2001 tank. Samples were taken every $4 \mathrm{~h}$ for biological parameter determination. DDNA: dissolved DNA; other parameters as in Fig. 1. Error bars indicate standard deviations estimated from multiple measurements (for DDNA, $\mathrm{n}=6$; others as in Fig. 1) rates have been reported in the literature, ranging from $0.0042 \mathrm{~h}^{-1}$ (Zachary 1976) to $1.1 \mathrm{~h}^{-1}$ (Bratbak et al. 1992). The lower values were from the measurements of human pathogen and coliphages decay in the marine environment as determined by plaque assay (Kapuscinski \& Mitchell 1980); the higher values were from the direct enumeration of natural viral populations in the marine environment after the inhibition of new viral production (Bratbak et al. 1992). To obtain a range of estimations of \% bacterial population lysed by viruses, we chose the lowest and the highest values of the viral decay rate measured by plaque assays $\left(0.004\right.$ and $0.096 \mathrm{~h}^{-1}$; Table 2), and the lowest and the highest decay rate determined by the direct counts method (0.3 and $1.1 \mathrm{~h}^{-1}$; Table 2). The average burst size for cultured marine phages (mean 185, $\mathrm{SD}=179$, $n=52$; Børsheim 1993) was also used in the calculation, as well as the burst size estimated for the natural marine viral population by streptomycin treatment (average 50, range 10 to 300; Heldal \& Bratbak 1991).

Using viral direct counts at any one sample time $\left(V_{n}\right)$ during the diel study for each chosen decay rate, the viral abundance at the next sample time without new phage production $\left(V_{n+1}^{\prime}\right)$ was calculated using the following equation:

$$
R=\left(\ln V_{n}-\ln V_{n+1}^{\prime}\right) /\left(T_{n+1}-T_{n}\right)
$$

where $R=$ viral decay rate; $T_{n}=$ time when the $n$th sample was taken; $T_{n+1}=$ time when the $(n+1)$ th sample was taken; $V_{n}=$ viral abundance at time $T_{n i}$ $V_{n+1}^{\prime}=$ estimated viral abundance without new phage production at time $T_{n+1}$.

Solving the equation for viral abundance $\left(V_{n+1}^{\prime}\right)$, and assuming all the viruses enumerated in each sample were lytic bacterial phages, the difference between the actual viral direct counts at time $T_{n+1}$ and the value of $V_{n+1}^{\prime}$ is the new production of viruses from bacterial lysis:

$$
V_{\text {new }}=V_{n+1}-V_{n+1}^{\prime}
$$

where $V_{\text {new }}=$ new viral population; $V_{n+1}$ is viral direct counts at the time $T_{n+1}$.

According to the burst size and the bacterial direct counts at that sample time $\left(B_{n}\right)$, the bacterial mortality caused by the production of new phages is:

$$
B \%=\left[\left(V_{\text {new }} / B Z\right) / B_{n}\right] \times 100
$$

where $B \%=$ percentage of bacteria killed by viruses; $B Z=$ viral burst size; $B_{n}=$ bacterial direct counts at time $T_{n}$. When the viral direct count at a sample time was less than the estimated viral abundance without new phage production, indicating the new phage generation was not required $\left(V_{\text {new }}<0\right)$, the percentage of bacteria killed by viral lysis was represented by $0 \%$. 
Table 2. Estimates of viral lysis of bacterial populations based on an estuarine mesocosm using various viral decay rates and viral burst sizes. VDC: viral direct counts; BDC: bacterial direct counts; $R_{d}$ : viral decay rate per hour; $B Z$ : vlral burst size; $B \%$ : percent of bacteria lysed by viruses

\begin{tabular}{|c|c|c|c|c|c|c|c|c|c|c|}
\hline \multirow{3}{*}{$\begin{array}{l}\text { Sampling } \\
\text { time (h) }\end{array}$} & \multirow{3}{*}{$\mathrm{VDC} \times 10^{7}$} & \multirow[t]{3}{*}{$\mathrm{BDC} \times 10^{6}$} & \multicolumn{8}{|c|}{$\%$ of bacteria lysed in $4 \mathrm{~h}$} \\
\hline & & & \multirow{2}{*}{\multicolumn{2}{|c|}{$\begin{array}{c}R_{d}=0.0042 \\
B Z=185 \quad B Z=50\end{array}$}} & \multicolumn{2}{|c|}{$R_{d}=0.096$} & \multicolumn{2}{|c|}{$R_{d}=0.3$} & \multicolumn{2}{|c|}{$R_{d}=1.1$} \\
\hline & & & & & $B Z=185$ & $B Z=50$ & $B Z=185$ & $B Z=50$ & $B Z=185$ & $B Z=50$ \\
\hline $16: 00$ & $1.91 \pm 0.33$ & $3.84 \pm 0.11$ & 0.13 & 0.46 & 0.94 & 3.48 & 1.96 & 7.24 & 2.74 & 10.1 \\
\hline $20: 00$ & $1.97 \pm 0.25$ & $4.14 \pm 0.36$ & 0 & 0 & 0.37 & 1.36 & 1.34 & 4.98 & 2.08 & 7.72 \\
\hline $00: 00$ & $1.62 \pm 0.26$ & $3.9 \pm 0.07$ & 0.49 & 1.78 & 1.16 & 4.30 & 2.01 & 7.44 & 2.66 & 9.84 \\
\hline 04:00 & $1.94 \pm 0.86$ & $4.6 \pm 0.35$ & 0.62 & 2.32 & 1.32 & 4.86 & 2.18 & 8.08 & 2.84 & 10.5 \\
\hline 08:00 & $2.44 \pm 0.56$ & $4.5 \pm 0.35$ & 0 & 0 & 0.20 & 0.74 & 1.32 & 4.88 & 2.16 & 8.00 \\
\hline $12: 00$ & $1.83 \pm 0.44$ & $5.22 \pm 0.19$ & 0.95 & 3.52 & 1.52 & 5.64 & 2.25 & 8.32 & 2.79 & 10.3 \\
\hline $16: 00$ & $2.72 \pm 0.41$ & $5.67 \pm 0.04$ & 0 & 0 & 0 & 0 & 0.72 & 2.66 & 1.47 & 5.46 \\
\hline $20: 00$ & $1.58 \pm 0.19$ & $5.12 \pm 0.40$ & 2.27 & 8.40 & 2.77 & 10.2 & 3.40 & 12.6 & 3.89 & 14.4 \\
\hline $00: 00$ & $3.70 \pm 1.04$ & $4.14 \pm 0.24$ & 0 & 0 & 0 & 0 & 0 & 0 & 0.96 & 3.56 \\
\hline $04: 00$ & $0.78 \pm 0.05$ & $3.77 \pm 0.04$ & - & - & - & - & - & - & - & - \\
\hline \multirow{2}{*}{\multicolumn{3}{|c|}{$\begin{array}{l}\text { Mean } B \% \text { in } 4 \mathrm{~h} \\
B \% \text { per day }\end{array}$}} & 0.50 & 1.83 & 0.92 & 3.40 & 1.69 & 6.24 & 2.40 & 8.88 \\
\hline & & & 3.0 & 11.0 & 5.52 & 20.4 & 10.1 & 37.4 & 14.4 & 53.3 \\
\hline
\end{tabular}

The estimations of the percentage of the bacterial population lysed by viruses are shown in Table 2. During the diel study, between 0 and $14.4 \%$ of the bacterial populations were lysed every $4 \mathrm{~h}$ to maintain the observed viral population at each sample time. The highest percentage of bacteria lysed was found in the period of increasing viral population ( $28 \mathrm{~h}$ into the diel study; $20: 00$ to $00: 00 \mathrm{~h}$ ). The average percentage of bacteria lysed per day for each set of decay rate and burst size ranged from 3.0 to $53.3 \%$.

\section{Occurrence of lysogeny and bacteriocinogeny amongst marine bacterial isolates}

Bacteria isolated from estuarine, coastal oceanic environments and benthic invertebrates were screened for lysogeny by mitomycin $C$ induction of prophages. Fig. 4 shows the electron micrographs of the phagelike particles and the bacteriocin-like particles (empty phage heads and tail assemblies) from the mitomycin $C$ induced lysates. Since no sensitive hosts to those particles have been found yet, we cannot be certain that these phage-like particles were temperate phages or bacteriocins. Therefore, bacteriocinogenic and lysogenic strains are not differentiated. The results of these induction experiments indicated that nearly half $(43.1 \%)$ of the bacteria tested were found to contain inducible prophages or bacteriocin particles (Table 3 ). Lower percentages of lysogenic and bacteriocinogenic bacteria $(29.1 \pm 9.52 \%)$ were found in the eutrophic environments (St. Petersburg Pier, Northshore Beach. Key Largo Canal). The higher percentages (64.2 +

Table 3. Occurrence of lysogeny/bacteriocinogeny (lys./bac.) amongst bacterial isolates as determined by mitomycin $C$ induction

\begin{tabular}{|c|c|c|c|}
\hline $\begin{array}{l}\text { Sampling site } \\
\text { (Florida, USA) }\end{array}$ & $\begin{array}{l}\text { No. of isol. } \\
\text { examined }\end{array}$ & $\begin{array}{c}\text { No. of } \\
\text { lys./bac. }\end{array}$ & $\begin{array}{c}\% \\
\text { lys./bac. }\end{array}$ \\
\hline St. Petersburg Pier, Tampa Bay & 10 & 4 & \\
\hline $\begin{array}{l}\text { North Shore Beach, } \\
\text { St. Petersburg, Tampa Bay }\end{array}$ & 11 & 2 & \\
\hline Key Largo, canal Site 1 & 6 & 2 & \\
\hline Key Largo, canal Site 2 & 4 & 1 & \\
\hline Hawk Channel, Key Largo & 5 & 3 & \\
\hline Mosquito Bank, Key Largo & 2 & 1 & \\
\hline Algae Reef, Key Largo & 4 & 2 & \\
\hline Tarpon Sound, Key Largo & 3 & 3 & \\
\hline Blackwater Sound, Key Largo & 4 & 3 & \\
\hline Sponge tissue, Key Largo Site 6 & 2 & 1 & \\
\hline Total & 51. & 22 & 43.1 \\
\hline
\end{tabular}

Fig. 4. Transmission electron micrographs of phage-like particles and bacteriocin-like particles. (A) Tailed phage found in mitomycin $C$ induced lysate of a bacterium isolated from the seagrass environment of Hawk Channel, Key Largo, Florida, USA. (B) Tailed phage-like particle from the lysate of a bacterium (\#19) isolated from the St. Petersburg Pier, Florida. (C) Tailed phage found in the lysate of a bacterial isolate from the coral reef environment of Mosquito Bank, Key Largo. (D) Empty phage heads and tail assemblies found in the induced lysate of St. Petersburg Pier bacterial isolate \#5. (E) Tailed phage and phage tall assemblies found in the lysate of bacterial isolate from a canal of Key Largo. (F) Empty phage heads and tail assemblies found in the lysate of a bacterial isolate from a canal of Key Largo. Scale bars $=0.1 \mu \mathrm{m}$ 

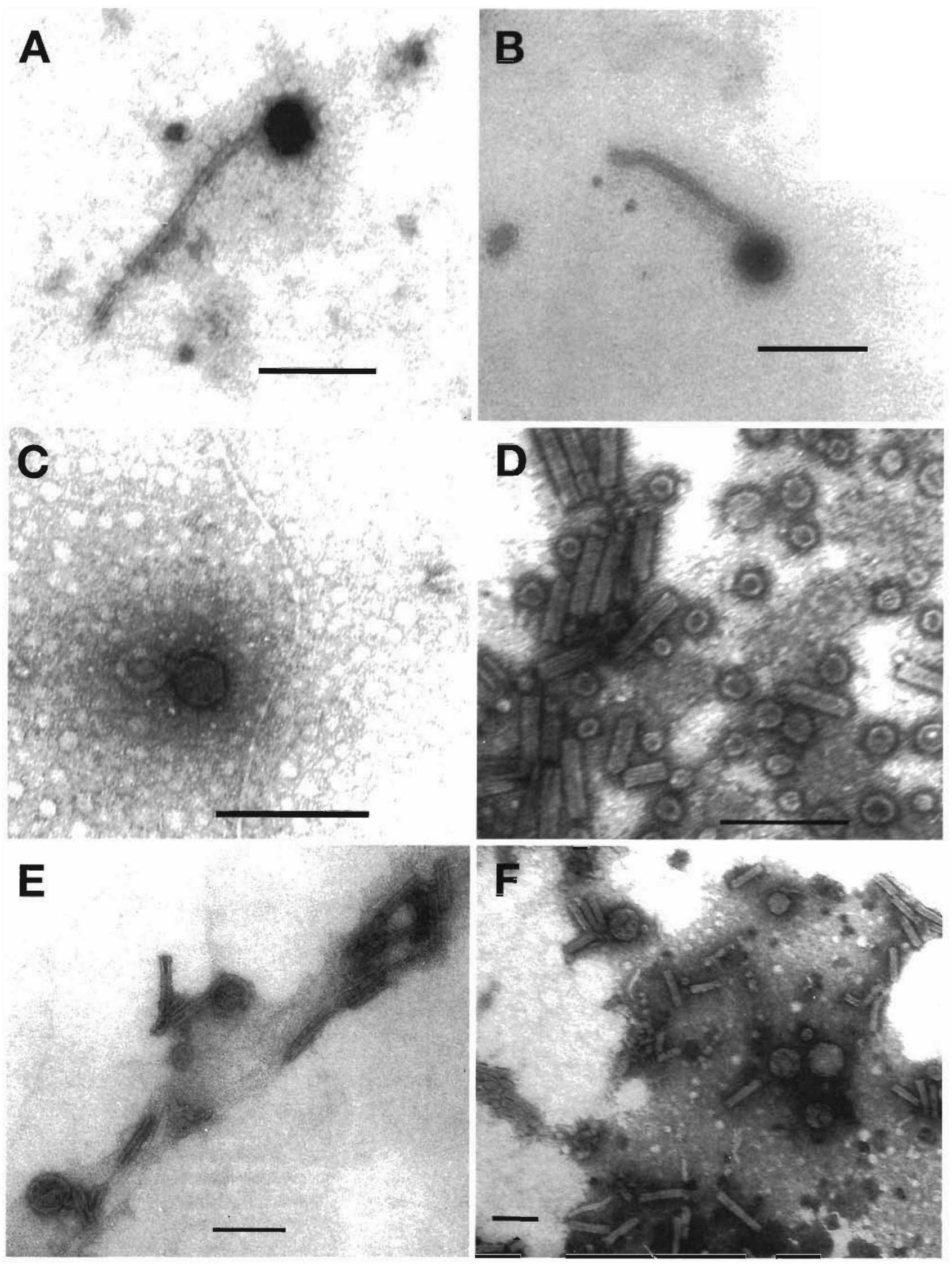
$20.1 \%$ ) were found in more pristine coral reef and reef lagoon environments. These results suggest that lysogeny and bacteriocinogeny may be common occurrences in the marine environment.

\section{DISCUSSION}

To understand the role of viruses in the marine environment, it is important to know the temporal distribution of viral abundance in relation to the distribution of bacteria, phytoplankton and other biological parameters. Previous studies on viral abundance in the marine environment have focused on spatial distribution (Hara et al. 1991, Wommack et al. 1992, Boehme et al. 1993, Cochlan et al. 1993). In this study, we demonstrated that the distribution of viral abundance has a strong seasonal pattern with highest concentrations in the summer months and lowest concentrations in winter. Viral concentrations were found to correlate negatively with salinity ( $\mathrm{r}=-0.803$ ), and positively with chl a ( $\mathrm{r}=0.725)$, temperature $(\mathrm{r}=0.649)$ and bacterial abundance $(\mathrm{r}=0.561)$.

The correlations of viral counts with chl a and bacterial abundance as found in the seasonal study were not surprising, because these relationships were also demonstrated in the spatial distribution of viral abundance (Paul et al. 1991, 1993, Boehme et al. 1993, Cochlan et al. 1993). However, these relationships may only reflect the variation in all the biological parameters as a function of seasons.

A similar negative correlation $(r=-0.970)$ between viral abundance and salinity has also been observed in a study of viral abundance in the coastal environment around Key Largo (Paul et al. 1993). It seems unlikely that salinity directly regulates viral abundance, and such a correlation was not found in offshore waters (Boehme et al. 1993). One possible explanation of this phenomenon may be that freshwater input from rivers and land runoff transported viruses into the estuarine environment, therefore resulting in the strong negative correlation observed. The other possibility might be that the input of nutrients brought in with the freshwater pulses caused an increase in microbial production and activity resulting in viral production. This explanation seems most plausible. A third, less likely possibility is that freshwater input resulted in induction of viruses from lysogeny. It has been hypothesized that most viruses in aquatic environment are temperate rather than virulent (Freifelder 1987, Heldal \& Bratbak 1991). The production of bacteriophages by induction of lysogeny may be an important source of viral production. The factors which cause the induction of temperate phages in the environment (e.g. UV light, nutrients, pollutants) are not yet fully understood.
VBR has been used to characterize the relationship between bacterial and viral communities (Hara et al. 1991, Wommack et al. 1992). The VBR was highest in September through October in the present seasonal study. These results are in agreement with the observations of Wommack et al. (1993), except that they reported the lowest VBR in the September sample which contained higher bacterial counts and the lowest viral counts (Wommack et al. 1992). The VBR values in this study ranged from 0.9 to 9.13 , lower than other published values for estuarine environments (Hara et al. 1991, Wommack et al. 1992). It is possible that our means of concentrating viruses (ultrafiltration) may result in underestimation of viral counts (perhaps the smallest viruses) and thereby result in lower VBRs. However, previous studies have shown that the ultrafiltration technology used in this study efficiently concentrated viruses (Paul et al. 1991). On the other hand, in our experience, it is difficult to identify viral particles from other electron-dense particles at magnifications of 48000 to $60000 \times$, and enumeration of virus-like (or size) particles at $36000 \times$ or lower as described by other investigators (Wommack et al. 1992) may have overestimated the viral counts by including the virus-sized colloids (inorganic particles or organic detritus) which have been recently reported to be abundant in the marine environment (Wells \& Goldberg 1991, 1992).

Because viral infectivity was sensitive to solar UV radiation, Suttle \& Chen (1992) suggested that there should be a strong diel signal in the abundance of infective viruses. The fact that no diel rhythm in viral abundance was detected during the present diel study suggested that a large proportion of the viruses in seawater observed by TEM may not be infective. Our results do not negate the possibility of diel rhythms in viral abundance in aquatic environments. The use of a tank in the present study may have induced artifacts (e.g. edge effects) not found in native aquatic environments.

Several methods have been used to estimate the viral contribution to bacterial mortality (Proctor \& Fuhrman 1991, Bratbak et al. 1992). One method is to calculate the bacterial mortality required to maintain viral abundance in an environment. The first estimation of virus-induced bacterial mortality using this method was by Bratbak et al. (1992). They assumed that the average viral abundance was the same from day to day, and then calculated the amount of bacterial mortality required per day to maintain this viral abundance. Because both viruses and bacteria are dynamic members of the microbial community, we think it is more reasonable to estimate the viral contribution to bacterial mortality on a time scale of hours. In this study, we modified Bratbak's model (Bratbak et al. 1992) by using viral direct counts and bacterial direct 
counts from each sampling time and estimating the viral contribution to bacterial mortality every $4 \mathrm{~h}$. The results of these estimations indicated that the average viral lysis of bacteria was less than $8.88 \%$ over a $4 \mathrm{~h}$ period. The maximum estimation of bacteria lysed by viruses in this study was $53.3 \% \mathrm{~d}^{-1}$ (average 19.4), which is considerably lower than the result using Bratbak's model (146.4\%).

When the decay rate of $0.0042 \mathrm{~h}^{-1}$ was used, nearly half of the sample times had no virus-induced bacterial mortality. These results may suggest that the actual viral decay rates were underestimated at those sample times. Viral decay rates have been shown to change within 24 h (Bratbak et al. 1992). Any average decay rate used through a day may overestimate viral population decay at one time and underestimate it at another. When viral mortality in bacterial populations was estimated for $4 \mathrm{~h}$ periods based on a wide range of reported viral decay rates, the results suggested that the decay rates of $0.096 \mathrm{~h}^{-1}$ and $0.3 \mathrm{~h}^{-1}$ may most closely represent actual decay rates, corresponding to the viral lysis of 5.52 to $37.4 \%$ of the bacterial population per day.

Since more than $90 \%$ of known phages are temperate (Freifelder 1987), it has been hypothesized that most of the viruses in the marine environment are temperate rather than virulent (Bratbak et al. 1990, 1992, Heldal \& Bratbak 1991). The results of our study are in agreement with this hypothesis, indicating that lysogenic bacteria may be a significant proportion of marine bacterial populations. However, we have only examined cultivatable bacteria, which may not be representative of the bacteria present in the oceans. Also, we have not yet been able to differentiate bacteriocinogeny from lysogeny. Both are inducible by mitomycin $C$ and produce phage-like particles (Bradley 1967). Bacteriocins and prophages are also related at the genetic level (Reeves 1965, Holloway \& Krishnapillai 1979). However, bacteriocins will neither infect bacteria nor replicate, and their role in the marine ecosystems may be significantly different from bacteriophages.

Freifelder (1987) suggested that there are 2 conditions that stimulate a lysogenic response of a temperate phage: (1) depletion of nutrients in the growth medium and (2) a high multiplicity of infection. Kokjohn et al. (1991) also observed that a natural phage isolate exposed to starved cells appears to establish a pseudolysogenic relationship with its host. The greater percentage of lysogeny observed in bacteria isolated from the offshore environment in this study may have been caused by lower nutrient conditions in those environments. Because no systematic attempt was made to survey the percentage of lysogens with respect to environmental conditions, these percent- ages may not reflect the proportion of lysogens in the natural population. Only the cultivatable and easily isolated bacteria were tested in this study. Future study will evaluate the ecological and genetic importance of lysogenic bacteria and temperate phages in the marine environment.

Acknowledgments. This work was supported by NSF grants OCE 9022036 and OCE 9115942 to J.H.P. This work was also partially supported by IBS (Institute for Biomolecular Science at Univ. of South Florida) graduate student summer fellowships to S.C.J We also thank Scott L. Pichard for his help in the sampling for the diel study.

\section{LITERATURE CITED}

Ackermann, H., DuBow, M. S. (1987). Lysogeny. In: Viruses of prokaryotes, Vol. 1, General properties of bacteriophages CRC Press, Boca Raton, p. 87-101

Ahrens, R. (1971). Untersuchungen zur Verbreitung von Phagen der Gattung Agrobacterium in der Ostsee. Kieler Meeresforsch. 27: 102-112

Bergh, O., Børsheim, K. Y., Bratbak, G., Heldal, M. (1989). High abundance of viruses found in aquatic environments. Nature 340: $467-468$

Boehme, J., Frischer, M. E., Jiang, S. C., Kellogg, C. A., Pichard, S. L., Rose, J. B., Steinway, C., Paul, J. H. (1993). Viruses, bacterioplankton, and phytoplankton in the southeastern Gulf of Mexico: distribution and contribution to oceanic DNA pools. Mar. Ecol. Prog. Ser. 97. 1-10

Borsheim, K. Y (1993). Native marine bacteriophages. FEMS Microbiol. Ecol. 102: 141-159

Bersheim, K. Y., Bratbak, G., Heldal, M. (1990). Enumeration and biomass estimation of planktonic bacteria and viruses by transmission electron microscopy. Appl environ. Microbiol. 56: 352-356

Bradley, D. E. (1967). Ultrastructure of bacteriophages and bacteriocins. Bacteriol. Rev. 31: 230-314

Bratbak, G., Heldal, M., Norland, S., Thingstad, T F. (1990). Viruses as partners in spring bloom microbial trophodynamics. Appl. environ. Microbiol. 56: 1400-1405

Bratbak, G., Heldal, M., Thingstad, T. F., Tiemann, B., Haslund, P. H. (1992). Incorporation of viruses into the budget of microbial C-transfer. A first approach. Mar. Ecol. Prog. Ser. 83: 273-280

Cochlan, W P., Wikner, J., Steward, G. F., Smith, D. C., Azam, F. (1993). Spatial distribution of viruses, bacteria and chlorophyll $a$ in neritic, oceanic and estuarine environments. Mar. Ecol. Prog. Ser. 92: 77-87

Deflaun, M. F., Paul, J. H., Davis, D. (1986). Simplified method for dissolved DNA determination in aquatic environments. Appl. environ. Microbiol. 52: 654-659

Freifelder, D. (1987). Molecular biology. Jones \& Bartlett, Inc., Boston

Hara, S., Terauchi, K., Korike, I. (1991). Abundance of viruses in marine waters: assessment by epifluorescence and transmission electron microscopy. Appl environ. Microbiol. 57: 2731-2734

Heldal, M., Bratbak, G. (1991). Production and decay of viruses in aquatic environments. Mar. Ecol. Prog. Ser. 72 $205-212$

Holloway, B. W., Krishnapillai, V. (1979). Bacteriophages and bacteriocins. In: Clarke, P. H., Holloway, B. J. (eds.) Ge- 
netics and biochemistry of Pseudomonas. Wiley, New York, p. 99-132

Holm-Hansen, O., Riemann, B. (1978). Chlorophyll a determination: improvements in methodology. Oikos 30:438-448

Jiang, S. C., Thurmond, J. M., Pichard, S. L., Paul, J. H. (1992) Concentration of microbial populations from aquatic environments by Vortex Flow Filtration. Mar. Ecol. Prog Ser. 80: 101-107

Kapuscinski, R. B., Mitchell, R. (1980). Processes controlling virus inactivation in coastal waters. Wat. Res. 14: 363-371

Kokjohn, T. A., Sayler, G. S., Miller, R. V. (1991). Attachment and replication of Pseudomonas aeruginosa bacteriophages under conditions simulation aquatic environments. J. gen. Microbiol. 137: 661-666

Kriss, A. E., Rukina, E. A. (1947). Bacteriophages in the sea Dokl. Akad. Nauk SSSR 57: 833-836

Moebus, K. (1987). Ecology of marine bacteriophages. In Goyal, S. M., Gerba, C. P., Bitton, G. (eds.) Phage ecology Wiley-Interscience, New York, p. 137-157

Ogunseitan, O. A., Sayler, G. S., Miller, R. V. (1990), Dynamic interaction of Pseudomonas aeruginosa and bacteriophages in lake water. Microb. Ecol. 19: 177-185

Ogunseitan, O. A., Sayler, G. S., Miller, R. V. (1992). Application of DNA probes to analysis of bacteriophage distribution patterns in the environment. Appl. environ. Microbiol. 58: 2046-2052

Paul, J. H. (1982). The use of Hoechst dyes 33258 and 33342 for the enumeration of attached and pelagic bacteria. Appl. environ. Microbiol. 43: 939-949

Paul, J. H., Jeffrey, W. H., DeFlaun, M. F. (1987). Dynamics of extracellular DNA in the marine environment. Appl. environ. Microbiol. 53: 170-179

Paul, J. H., Jiang, S. C., Rose, J. B. (1991). Concentration of viruses and dissolved DNA from aquatic environments by vortex flow filtration. Appl. environ. Microbiol. 57 2197-2204

Paul, J. H., Myers, B. (1982). The fluorometric determination of DNA in aquatic microorganisms employing Hoechst 33258. Appl. environ. Microbiol. 43: 1393-1399

Paul, J. H., Rose, J. B., Jiang, S. C., Kellogg, C. A., Dickson, L. (1993). Distribution of viral abundance in the reef environ. ment of Key Largo, Florida. Appl. environ. Microbiol. 59: $718-724$

This article was presented by S. Y. Newell, Sapelo Island, Georgia, USA
Proctor, L. M. Fuhrman, J. A. (1990). Viral mortality of marine bacteria and cyanobacteria. Nature 343: 60-62

Proctor, L. M., Fuhrman, J. A. (1991). Roles of viral infection in organic particle flux. Mar. Ecol. Prog. Ser. 69: 133-142

Proctor, L. M., Fuhrman, J. A. (1992). Mortality of marine bacteria in response to enrichments of the virus size fraction from seawater. Mar. Ecol. Prog. Ser. 87: 283-293

Reeves, P. (1965). The bacteriocins. Bacteriol. Rev. 29: 24-45

Replicon, J., Miller, R. V. (1990). Modeling the potential for transduction to stabilize a foreign genotype within an established microbial community. In: Abstr. 8th Internat. Cong. Virol., p. 117

Sieburth, J. McN., Johnson, P. W., Hargraves, P. E. (1988). Ultrastructure and ecology of Aureococcus anophagefferens gen. et sp. nov. (Chrysophyceae): the dominant picoplankter during a bloom in Narragansett Bay, Rhode Island, summer 1985. J. Phycol. 24: 416-425

Spencer, R. (1955). A marine bacteriophage. Nature 175: $690-191$

Suttle, C. A. (1992). Inhibition of photosynthesis in phytoplankton by the submicron size fraction concentrated from seawater. Mar. Ecol. Prog. Ser. 87: 105-112

Suttle, C. A., Chan, A. M. (1993). Marine cyanophages infecting oceanic and coastal strains of Synechococcus: abundance, morphology, cross-infectivity and growth characteristics. Mar. Ecol. Prog. Ser. 92: 99-109

Suttle, C. A. Chan, A. M., Cottrell, M. T. (1990). Infection of phytoplankton by viruses and reduction of primary productivity. Nature 347: 467-469

Suttle, C. A., Chen, F. (1992). Mechanisms and rates of decay of marine viruses in seawater. Appl. environ. Microbiol. 58: $3721-3729$

Wells, M. L., Goldberg, E. D. (1991). Occurrence of small colloids in sea water. Nature 353: 342-344

Wells, M. L. Goldberg, E. D. (1992). Marine submicron particles. Mar. Chem 40: 5-18

Wommack, K. E., Hill, T T., Kessel, M., Tussek-Cohen, E., Colwell, R. R. (1992). Distribution of viruses in the Chesapeake Bay. Appl. environ. Microbiol. 58: $2965-2970$

Zachary, A. (1976). Physiology and ecology of bacteriophages of the marine bacterium Beneckea natriegens: salinity. Appl. environ. Microbiol. 31: 415-422

Manuscript first received: August 11, 1993

Revised version accepted: October 21, 1993 